\title{
Estimular para Ensinar
}

Alcançar sucesso no ensino da Física e da Química, implica conhecer os meios aos quais os alunos são mais sensiveis, face ao seu nível etário, e proporcionar-lhes a informação pretendida, tanto quanto possível através desses meios. Deste modo, venho apresentar dois exemplos: Uma banda desenhada para o $8^{\circ}$ ano, dado que a idade dos 13 aos 15 anos é muito receptiva a este elemento, e uma letra para musicar para o $10^{\circ}$ ano, dado que a faixa etária dos 16-18 anos está muito sensibilizada para a música.

Alcançar sucesso no ensino da Física e da Química implica, cada vez mais, conhecer os meios aos quais os alunos são mais sensíveis, face ao seu nível etário.

A um aluno do $8^{\circ}$ ano, que se encontra no início do estudo da disciplina de Ciências Físico-Químicas, há que estimular-lhes os sentidos, de modo a encararem a disciplina de forma entusiástica, empenhando-se "sem dor" na aquisição dos seus conteúdos. O exemplo que apresento é uma Banda Desenhada (figura 1) onde se reproduz em os Super-Heróis que povoam o imaginário dos adolescentes dos 13 - 15 anos. A cor reforça o estímulo, e o aluno é conduzido para a disciplina de forma natural.

Para um adolescente dos 16-18 anos, que se encontra no $10^{\circ}$ ano, a música é sem dúvida um meio ao qual são muito sensíveis. Transformar conteúdos programáticos em música é uma forma de apelar ao empenho na disciplina, tanto pela forma como respondem à informação, como também por se proporcionar uma aula com um perfil diferente da aula tradicional. o exemplo que apresento é apenas a letra para musicar sobre o tema da Mole (figura 2). Tema que, "por tradição", o aluno manifesta sempre alguma dificuldade. Propositadamente, esta letra não é acompanhada de qualquer pauta, dado que o docente não tem obrigatoriamente que saber música para se poder socorrer da estratégia. Dado ser uma letra ritmada, pode ser interpretada até com estalar de dedos ao estilo "Rap", ou até sugerir-se à turma que apresen-
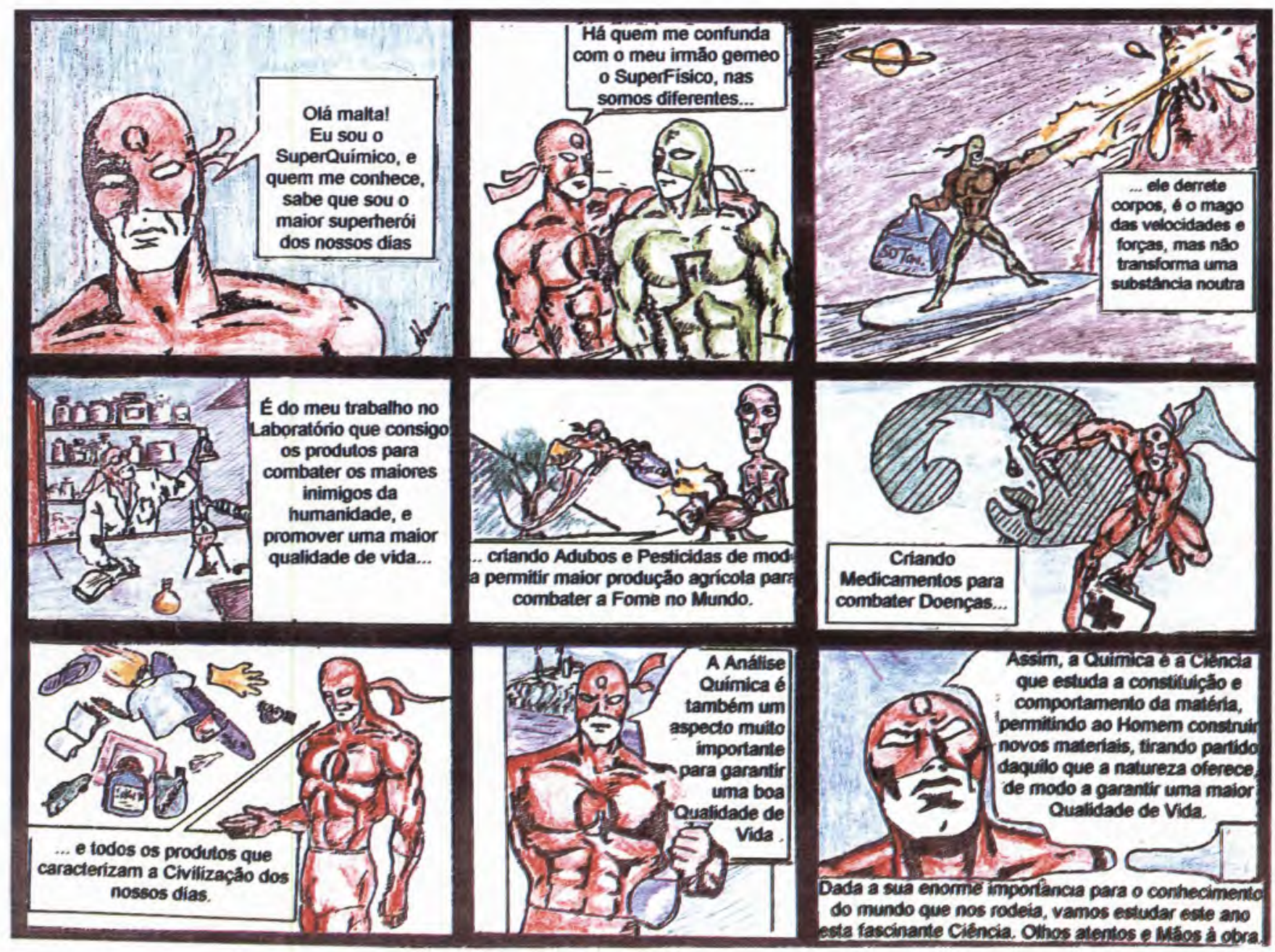
te uma música para a letra. O objectivo, continua satisfeito. Devo referir que preparei esta letra com o intuito de rever e consolidar conhecimentos sobre o tema em causa, e não para apresentar o conteúdo. Motivo pelo qual reforço o conceito através do refrão que separa as restantes estrofes, sendo cada conjunto de estrofes, dedicada a um subtema relacionado com o conceito de Mole.

Espero que as sugestões apresentadas possam merecer o interesse dos colegas para a tarefa de estimular o gosto pelo estudo da Física e da Química.

\section{Mole}

Dos átomos e das moléculas já nós ouvimos falar Mas são coisas tão pequenas Impossíveis de pesar

Como podemos trabalhar Com coisas de tal dimensão Usando o conceito de mole Que é o tema desta canção.

Seis vírgula zero vinte e dois Vezes dez levantado a vinte e três É uma mole e solução Tal como doze é uma dúzia, cem um cento e vinte cinco um quarteirão.

Este número de átomos de carbono Pesa apenas doze gramas e cabe na minha mão Mas se for outro elemento Este número de partículas Pesará de acordo Com a massa relativa do elemento em questão.

Posto isto então já sei Qual a massa a utilizar De cada um dos Reagentes E dos Produtos a formar

Experimento então na prática E avalio a previsão Divido o dado pelo esperado Que é o Rendimento da Reacção
Seis vírgula zero vinte e dois Vezes dez levantado a vinte e três É uma mole e solução

Tal como doze é uma dúzia, cem um cento e vinte cinco um quarteirão.

Este número de átomos de carbono

Pesa apenas doze gramas

e cabe na minha mão

Mas se for outro elemento

Este número de partículas

Pesará de acordo

Com a massa relativa

do elemento em questão.

Mas se trabalhar com gases

O que é difícil de pesar

Sei que uma mole em PTN

Ocupa o Volume Molar.

Vinte e dois vírgula quatro Litros de um gás ou vapor

É o volume ocupado

Pela quantidade da mole.

Seis vírgula zero vinte e dois

Vezes dez levantado a vinte e três

É uma mole e solução

Tal como doze é uma dúzia, cem um cento

e vinte cinco um quarteirão.

Este número de átomos de carbono

Pesa apenas doze gramas

e cabe na minha mão

Mas se for outro elemento

Este número de partículas

Pesará de acordo

Com a massa relativa

do elemento em questão. 